\title{
The Model of Supervision of Environment Management in Mineral and Coal Mining
}

\author{
Nurul Listiyani ${ }^{1^{*}} \quad$ Muzahid Akbar Hayat ${ }^{2}$ \\ 1.Faculty of Law, Universitas Islam Kalimantan Muhammad Arsyad Al Banjari Banjarmasin \\ 2.Postgraduate Programme, Master of Communication, Universitas Islam Kalimantan Muhammad Arsyad Al \\ Banjari Banjarmasin
}

\begin{abstract}
The utilizing concept of natural resources is closely related to the country's obligation to formulate policies (beleid), to make arrangements (regelendaad), to do arrangements (bestuursdaad), to conduct management (beheersdaad), and to do the supervision (toezichthoundendaad). The main effort that has to be made in environmental management is pollution prevention and environmental breakdown, where the Article 1 number (2) UUPPLH states that one of the preventive efforts is to do the systematic supervision and integrated supervision. The state administrative law aspect, the supervision is defined as an activity process comparing what is being carried out, or conducted to what is being desired, planned or ordered. Protection and management of environmental in administrative construction law relates to the protecting and managing the environment by the government.The protecting and environment managing by the government based on the government validity theory actions (rechmatigheid van bestuur) must fulfill the legal requirements (rechtmatigheid and wetmatigheid), involving three aspects, those are: authority, procedure, and substance. The measurement used is written / statutory regulations and unwritten regulations as Good Governance General Principles (AUPB).
\end{abstract}

Keywords: environmental, coal mining, supervision, environmental management.

DOI: $10.7176 / \mathrm{JLPG} / 88-10$

Publication date: August $31^{\text {st }} 2019$

\section{Introduction}

Based on Sectorial, the Article 141 paragraph (1) Laws Number 42009 (Republic of Indonesian Gazette of 2009 Number 157) about Mineral and Coal Mining (furthermore written in the Minerba law) states that one of the elements must be supervised by the Central Government or Regional Government are environmental management, reclamation and post-mining. The supervision is conducted by mine inspector on mining activities having IUP, IPR, or IUPK, according to authority. Furthermore, Government Regulation Number 55 of 2010 about Guidance and Meneral Implementation supervision of Management and Coal Mining, as regulation implementing of the provisions Article 144 of the Mining Law, regulating supervision conducted by mine inspector one of them is environmental permit.

When leaning to principles in Country Administrative Law, and then the mine inspectors do not have the authority to supervise the supervision environmental permits, because of the officials who have the authority to conduct that supervision are Environmental Supervision Officials, such as stipulated Law Number 32 of 2009 about Protection and Environmental Management (furthermore written UUPPLH).This sector arrangement appear to overlapping to environmental permit supervision. So the supervision purpose of environmental permits to prevent pollution and / or environmental damage does not maximally reached.

The results of the research to review various and regulations having a close interrelatedness with the mineral environmental management and coal mining, an integrated supervision model was found that moved from the Integrity Principle as regulated in UUPPLH. This supervision model is expected to be able to answer the overlapping problems of environmental management supervision in coal mining, where the research focuses on the effectiveness of implementing integrated supervision model integrating stakeholders and community participation.

\section{METHODOLOGY}

The research examining the supervision model, the researchers used sociolegal research methods. This sociolegal research is not identical with law sociology, a knowledge that has been widely known in Indonesia for a long time. The word of "socio" does not refer to sociology or social. Sociolegal academics generally study in law faculty. They conduct limitedly contact with sociologists, because this study was hardly developed in sociology or other social. Based on, sociolegal study is law studies, which use a methodology approach to social science in a broad meaning. (Irianto \& Sidharta, 2011).Quoting from Wheeler and Thomas' opinion (Banakar \& Travers, 2005), sociolegal research is an alternative approach examining doctrinal research of law. The word of "socio" in socio-legal research presents the interrelationship between contexts in which law exists (an interface with a context within which law exists). Why when a socio-legal researcher uses social theory for analytical aims, they don't often aim to pay attention to sociology or other social sciences, but law and legal researches. As a "new" 
school of thought, this research through various advanced books and journals has illustrated theories, methods, and topics increasingly becoming an aspirant attention. Sociolegal research becomes the method chosen to examine the oversight model of environmental management because it examines supervision condition as part of intrinsically preventive law enforcement, by looking at supervision as a value system and a social norm with goals to be achieved to solve law issues related to overlapping norm supervision of Mineral environmental management and coal mining. The analysis conducted is by thinking of "order of logic" thinking, which develops a mindset based on the most fundamental and essential analysis and to material analysis. (Susanto, 2007)

\section{RESULT AND DISCUSSION}

\subsection{Theoretical of Environmental Management Supervision}

The large Indonesian Language Dictionary explains the meaning of supervision as ownership and direction of the company running policies, while controlling are described as supervision progress (tasks) by comparing results and targets regularly basis and adjusting the business (activities) with the supervision results. (Pustaka,1997).

Supervision is the main instrument in administrative law which is part of preventive law maintenance efforts. Law maintenance is an effort to realize community legal compliance. Supervision is aimed prevent the occurrence of violation while as early as preventing the occurrence of violations to avoid worse consequences.

According to G. Terry, supervision is focused on evaluation actions and corrections to the results that have been achieved, with the intention of the results in accordance with the plan. H. Fayol, argues that essence supervision is an act of assessing (testing) whether something has ran according to a predetermined plan. By the supervision, the errors can be found, which ultimately can be corrected and the most important thing the errors doesn't not be repeated. (Fauzi, 2013).

So philosophically, supervision is an act of assessing or examining whether something has ran according to a predetermined plan. With this supervision, the errors can be found which ultimately can be corrected. The supervision must be conducted as early as possible so that feedback can be obtained to do improvement if there are errors or irregularities. In a law perspective, supervision is aimed to avoid mistakes, whether intentional or unintentional, as a preventive effort, or correcting too if there is an error, as a repressive effort. In practicing, the existence of control is often seen as a means to prevent any form of governmental deviation from what has been outlined. So the location supervision essence here. This is illustrated in a literal sense, where preventive supervision is supervision avoiding, preventing means keep an activity from falling into error, so that permits of environmental supervision conducted by mine inspectors and environmental supervisors is aimed to keep business person in charge of complying with environmental permit issued by the government / regional government.

Function of Preventive of business activities intersecting with the environmental is realized in the form of supervision conducted by authority in the sector of environmental supervision. According to George R. Terry, supervision is "Control is to determine what the result keeping on the plan", while Newman argues that supervision is "Control is the assurance that the performance conforms to plan". Both of these opinions give the understanding that supervision is focused on 2 (two) things, that is in the first process of conducting activities and at the evaluation stage and correction of the activity implementation. The definition is in accordance with the contents in the General Explanation of UUPPLH number 5 which states that "preventive effort in context of controlling environmental impact needs to be implemented by maximizing the supervision and licensing instruments.

\subsection{Authority of Environmental Management Supervision}

To supervise the compliance of the business person in charge of legislation and compliance on the environmental permit, Article 71 paragraph (2) mentioned that the Minister, governor, or regent / mayor can delegate their authority to the official / technical agency responsible for protection and environmental management. Furthermore, in paragraph (3) in the same Article, it is mentioned that the Minister, governor or regent / mayor stipulates that the environmental supervisors must conduct the supervision.

Environmental management in Country Administrative Law concerns 3 (three) aspects, those are: authority, procedure, and substance. Regarding the authority to supervise as one of the elements in the authority of the government / regional government in managing the environment, there is an overlap of authority over the supervision of compliance on business responsiveness to legislation and compliance with environmental permit. The UUPPLH and the Minerba Law sectoral regulate the authority supervising to the same object. Whereas in the Country Administrative Law there is a principle that officials authorized to issue licenses, it has the obligation to conduct the supervision of the permit.

In Article of 36 paragraph (4) UUPPLH mentioned that environmental permit is issued by the Minister, governor or regent / mayor according to their authority. The Minister referred to the article is the Minister of 
Environment and Forestry. Based on the principles adopted in Country Administrative Law, so officials authorized to supervise environmental permits issued are Ministers, Governors, or Regents / Mayors, where in Article 71 paragraph (4) it is mentioned that environmental supervisors are determined by the Minister, governor, or regent / mayor is a functional official who supervises.

\subsection{Environmental Management Oversight Model.}

UUPPLH as a law norm regulating environmental management functioning to summarize all environmental legislation into a system of Indonesian environmental law, so that it becomes a series of systematic environmental management arrangements, both vertically and horizontally, synchronizing and coordinating, to prevent regulation duplicative or contradictory between arrangements sector with one another related to the environment.

UUPPLH expressly states in Article 44 that: "Every formulation of laws and regulations at the national and regional levels must pay attention to the protection of environmental functions and the principles of environmental protection and management in accordance with the provisions stipulated in this law".

The extravagance of UUPPLH becomes a protection law for sector regulations affirmed general explanation in UUPPLH which states that a clear, explicit and comprehensive legal system for environmental protection and management is needed to ensure legal certainty as a basis for the protection and natural resources management and other development activity. Beside the juridical study, the need for UUPPLH as a law protecting to another environmental sector regulation also leaving from the characteristics and nature of environmental law itself, those are incidental, commensal, partial, and sector. (Kahfi, 2014).

\subsection{The Principle of Integration as the Foundation for the Integration Concept of Coal Mining} Management Regulations

\subsubsection{The Nature of a Law Principle as the Basis of Legal Norms}

The essence of every rule of law has a philosophical basis in the form of principle or it can also be called a principle. The position of the legal principle in all legal systems regulating norms system according to Agus Yudha Hernoko has a very important role. The legal principle is the foundation or foundation supporting strength of a legal norm.

An understanding of a legal norm and why a legal norm is promulgated can be followed from the legislative ratio, so that even though the principle of law is not a legal norm, there is no legal norm that can be understood without knowing the legal principles contained inside it. Related to the concept of the principle of law, Y. Sogar Simamora expressed his opinion:

Legal principles are needed as a basis for establishing legal rules as well as a basis on solving legal problems arising when the available legal rule is not adequated. The law principles or legal principle is one of the important objects in the study of law. The discussion of legal principles is usually juxtaposed with legal rules or legal rules to have a clear illustration regarding the differences.

\subsubsection{The meaning and concept integration function}

Integration comes from English integration meaning perfection or whole. The definition of concept integration grammatically based on the Large Dictionary of the Indonesian Language Center is mixing so it becomes a whole and round unity. (Nasional, 2012). While the cohesiveness meaning according to the large Indonesian Dictionary is not grammatically given meaning. Integration is interpreted in nouns as "integrated matters"

The principle of integration in the protection and management of the environment has also been mentioned in the Rio Declaration, which explicitly mention the existence of the Principle of Integration which mentioned "legal environmental protection constitutes an integral part of the development process and cannot be considered in isolation from it". Integration is related to planning, implementation, and supervision. Integration also includes spatial planning, protection of environmental resources, and integration of management at government levels, they are the central and regional levels.

Conceptually, both meanings above, the meaning are integration and integration, clearly show the scope of the environment which is integral (one unit / integrated). Then the concept has consequences on the scope of environmental management, including the scope of the environmental management supervision system.

The integration principle which support of author effort creates to supervisory model in coal mining management, it becomes one of the "pillar" supporting the implementation of environmental protection and management in order to achieve the goal of environmental legislation, that is "sustainable development accompanied by good governance aims to improve welfare and justice for present and future generations ".

Ideally to the cohesion principles, a legal system is created that integrates regulating 
environmental legal aspects of the sector in its management and implementation which has a close relationship with the environment, one of which is the coal mining sector.

The principle of integration is distinguished by, first, the types of integration and implementation of licensing arrangements. Second, integration in spatial planning based on patterns or characteristics of environmental resources. Third, in integration authority. In relation to integration of environmental management, according to N.H.T. Siahaan, that is: (Siahaan, 2017).

a. The government establishes national environmental policies and procedures in an integrated manner by each competent and relevant government agency, all the community and perpetrator of customs, and the value of life in the community.

b. Integration includes planning and implementation.

c. Integration includes spatial planning, protection of natural resources (biotic resources), protection of man-made resources, protection of biological resources and ecosystems (biotic resources), cultural heritage, biodiversity, and climate change.

d. The integration of management at the national level is conducted coordinatively by the Minister.

e. Integration can be conducted by delegating the authority of environmental management to equipment in the regions, with the principle to give some of the affairs to regional household affairs.

Another opinion mentions that the principle of integration is implemented in 3 (three) law instruments in UUPPLH, they are Environmental Protection and Management Plans (RPPLH), Strategic Environmental Research (SEA), and environmental permits. (Akib, 2012).

UUPPLH as a legal norm regulating the environment, recognizes 2 (two) types, they are environmental permits and business or activity permits. Both types of permits are included in scope and are submitted to UUPPLH.

Business licenses or activity is referred to UUPPLH is permitting to do environmental resources, including the use of coal resources. In its regulation, the use of natural resources is regulated by the sector so it "though" to be separated of environmental regulation. Even if it is accurated from the article that reflects integration in UUPPLH as explained above, the integration pervades the integration of environment element, in management integration and stakeholder integration.

\subsection{Environmental Management Supervision Regulations of Reconstruction on Mineral and Coal} Mining

\subsubsection{Environmental Management Supervision Arrangements of Integration on Coal Mining}

Environmental law of enforcement pass through administrative legal instrument is the first and prominent step to it achieves regulatory compliance. It is said as the first step, because the actual environmental problem will not occur if the environmental administration legal instrument is implemented and enforced properly.

J.B.J.M. Ten Berge stated that there are two administrative law enforcements, the first supervision and the second are administrative sanction. Supervision is a preventive step to implement compliance, while the sanction application is a repressive step to enforce compliance. (Berge,1994).

In administrative preventive law, supervision is the official main duty authorized to give environmental permits. In administrative law, there is a general principle that always becomes main guideline, the official who is authorized to give responsible for permission in supervising on permits given.

Permission that have been given are not merely a formal requirement that must be fulfilled by the business doer, but substantially must also be fulfilled according to the requirements required in permit given. If you see the contents of article in UUPPLH which regulates supervision, then there are two things that are authorized by the government and regional government to be monitored, they are the compliance supervision of business doer and activity on the provisions stipulated in legislation in protection major and environmental management and compliance supervision to the person who get responsible for business and activities on environmental permits. The aim of this supervision has similarities to supervision aim regulated in Minerba Act, where the Article 141 paragraph (1) is, it is stated that supervision conducted by the Minister, governor and regent / mayor form environmental management supervision, reclamation and post-mining Environmental Management is referred to the article 141 paragraph (1) it is not further elaborated in General Provision or Explanation of Article by Article of Minerba act.

When analyzed from the supervision aim regulated in Minerba Act, so it is described that there is a similarity to the supervision aim regulated in UUPPLH, they are compliance supervision who get responsible for business and activity on legislation, it has an AMDAL document or UKL recommendation -UPL, as guarantor of business and activity on environmental permits. So concerning 
the regulation supervision should be conducted explicitly and integratedly.

\subsubsection{The Authority of Environmental Management Supervision of Integration on Coal Mining}

To conduct the supervisory activity, government officials must fulfill three validity requirements, they are: authority, substance and procedure. (Listiyani, 2018) The supervisory authority is related to government official who carry it out, where inside the UUPPLH is, it is regulated that an official authorized to supervise compliance on guarantor of business and activity on environmental permits are the Minister, governor or regent / mayor according to his authority. As regulated in Article 72 UUPPLH. But in Minerba Act of Article 140, it regulates that supervision is made by the Minister, governor, and regent / mayor on mining business conducting activity by mining business licenses holder (IUP), Populace's Mining Permit (IPR), or Special Mining Business Permit (IUPK).

From administrative perfective law, supervision is the main duty of official authorized to give environmental permit. In an administrative law, there is a general principle that always becomes main hold, the official who is authorized to give permission to responsible for supervising the permits given. The Permit that have been given is not only becomes formal requirements that must be fulfilled by the business doer, but substantially must also be fulfilled according to the requirements required in permit given. (Akib, 2015).

In doing environmental supervision, the Minister, Governor, or regent / mayor regulates that the environmental supervisor according to his authority. The environmental supervisor and regional environmental supervisor have authority to supervise to person who have responsible for environmental legislation and permits.

In the administrative law, licensing is closely related to supervision. The Minerba Act regulated that mineral and coal mining supervisor are Mine Inspector, and then in Article 141 paragraph (1), (2) and (3) to determine the authority mine inspector position, where the mine inspector has the authority to supervise 6 aspects they are:

1. Mining technical;

2. Mineral and coal resources conservation;

3. Mining occupational health and safety;

4. Mining operations safety;

5. Environmental management, reclamation and post mining; and Goods Utilization,

6. Serving, technology and engineering capabilities and domestic design.

The law implication No. 23 of 2014 on coal mining management is to supervise of mineral and coal mining activities becomes affair of the Ministry of Energy and Mineral Resources through mine Inspector and Supervisory Officer. The Provincial Government is only authorized to manage the business, so supervision cannot be de-concentrated. Beside, the Mining Inspector ordered in the field no longer has institutions in provincial and district / city areas.

The Government Regulation of Indonesia Republic of article 28 Number 55 of 2010 detailing the scope of environmental management supervision, which is same the article also regulates about reclamation and post-mining supervision, they are:

a. Management and environment monitoring according to environmental management documents or owned and approved environmental permits;

b. Arrangement, recovery and land repairing according to its designation;

c. Determination and disbursement of reclamation guarantees;

d. Post-mining management;

e. Determination and disbursement of post-mining guarantees; and

f. Fulfillment of environmental quality standards according to statutory provisions.

The Article of 28 paragraph (2) PP No. 552010 regulates that the environmental management supervision, reclamation and post-mining is done by mine inspector and coordinates to supervisory official in environment major and reclamation.

Based on provisions of Article 28 paragraph (2) mentioned above, then terminologically the environmental management supervision in mining business is not done by mine inspector independently, but the coordination must be established to supervisory official of environmental major.

By referring to legal norms contained in the Country of Administration Law, Environmental Protection, Management Law and Mineral and Coal Law, they are on supervision which have responsible for business and coal mining activity of laws and compliance to the environmental permit, an environmental supervisor are officials which have the authority to conduct the environmental management supervision as referred to Article 141 paragraph (1) item H of Law Number 42009 about Mineral and Coal Mining.

Thus, the mine inspector as the supervisor of environmental management as regulated in Law No. 4 of 2009 about Mineral and Coal Mining, actually it does not have authority to conduct supervision on 
person who has responsible for business and activities on legislation and compliance and environmental permits.

\subsection{Environmental Management of Supervision Model}

From the research results conducted, so the supervision model standing on theory and concept. In the context of prescribing supervision model, the legal norms governing the environmental management supervision in coal mining, it is reviewed based on establishing legislation principle and its suitability vertically and horizontally to another law and regulations which also regulate the same material content. The legislation theory as described above it is made into a concept grand theory model. By relying on the hypothesis that the pattern of legislation as an example of legal policy used in this country, it is influenced of legal politics, so at the practical level legal product is often found that is not according to the values or intention required or establishing reason legal norms is synchronized to the law purpose itself. So by making theory of legislation as the theoretical basis in this research, the result accuracy of the research likes conceptual model can be accounted for.

The Authority theory is used as a strong analysis aimed to analyze the regulation of the right and obligation of the government or local government in monitoring the management of coal mining as a consequence to dominate the state's right controlling natural resources.

The supervision concept model relies on supervisory theory put forward by experts. According to G. Terry, supervision is focused on evaluation actions and correction to the result that has been achieved, by intention of the result according to the plan. H. Fayol, argues that essence supervision is an act of assessing whether something has gone according to a predetermined plan. By supervising, the errors can be found, which ultimately can be corrected and the most important thing it does not repeat the errors. The second aspect monitored is regulated in Article 72 UUPPLH the compliance is accounted for business and activity on environmental permits, which is according to the researcher the most important item in supervision. Because it is issued to environmental permits, it means that the person accounted for business and activity has fulfilled the legislation provision as condition is issued to environmental permits, that is Amdal assessment likes environmental feasibility decisions or UKL-UPL recommendations. The supervision model of prescription is as follows:

Supervision is a series of activity done as an integrated by the Environmental Supervisor official and the Regional Environmental Supervisor official to know, ascertain, and determine the level accounted for business and activity on provisions regulated in environmental permit, legislation protection and environmental management major coordinates to the sector supervisor.

The definition supervision above clearly illustrates that environmental management supervision, in this research context, supervision of compliance to the person who accounted for the coal mining business on environmental legislation and permit, it is a new supervision model emphasizing integration and coordination including the following elements:

1.The equal aim of supervision is an environmental supervision permits issued by the Ministry of Environment Ministry and Forestry, the governor, regent or mayor.

2. Involving sector institute, they are the Environment Ministry and forestry, and the Energy Ministry and Mineral Resources.

3 The equal goal is to ensure that environmental management in coal mining has appropriated to environmental permit that has been issued.

4 Integrated, the supervisory authority related is located on environmental permit institute.

5 Coordination, between institute that has relevance and authority in minerals mining and coal.

The supervisory model that researcher offer has fulfilled integration principle meaning which becomes one of the principles in environmental management protection. Where the integration pervades environmental integration elements, in integration management and stakeholders. Beside, the integration concept also offered fulfilling the environmental supervision element proposed by A.V. Van den Berge, they are the existence of integration authority regulation and coordination. In supervision Integration of coal mining management is purposed as a fusion of competencies, but the coordination is a collaboration to carry authority out of working together in the expression of autonomous competences. Mr. Handoko defines coordination as integrating goals process and activity on separated units (departments or functional majors) an organization. The lexicon supervision model described consists of elements:

- There is a process

- Carried out seriously

- There are items monitored

- To reach certain goals

When is being related to environmental management supervision in perspective of UUPPLH and the Minerba Law, then the elements in lexicon supervision model have been fully manifested. In Article 1 
number (2) UUPPLH mentions the one of the prevention effort is to implement systematic supervision and integrated. Supervision is processing to establish performance measures and taking actions that can support the expected achievement results according with the predetermined performance.

\section{Conclusion}

Based on legal analysis results issues that have been described, then it can be concluded that the environmental management proposed to article 141 paragraph (1) h of the Minerba Act is related to environmental management document and environmental permits. But in UUPPLH, environmental management includes broad meaning and more comprehensive meaning, they are systematic and integrated effort done to conserve environmental function and prevent pollution and environmental damage including plan, utilization, maintenance control, supervision and enforcement law.

By reality, environmental management which becomes supervision item in Minerba Act, it has similarities supervision stipulated item in Law No. 322009 about Protection and Environment Management, that is compliance person who has responsible for business and activities on legislation - environmental and permission. So by referring to Country Administrative Law, the authority to do environmental management supervision is on Environment and Forestry Ministry.

\section{References}

Irianto, S. \& Sidharta, 2011. Metode Penelitian Hukum: Konstelasi dan Refleksi. BPHN, pp. 1-18.

Irianto, S. \& Sidharta, 2011. Memperkenalkan Studi Sosiolegal dan Implikasi Metodologisnya. BPHN, pp. 1-18.

Banakar, R. \& Travers, M., 2005. Law, Sociology and Method. Onati: Hart Publishing Oxfordand Portland Oregon.

Susanto, A. F., 2007. Hukum dari Cosilence Menuju Paradigma Hukum Konstruktif Transgresif. Bandung: Refika Aditama.

Pustaka, B., 1997. Kamus Besar Bahasa Indonesia. Jakarta: Balai Pustaka.

Fauzi, A., 2013. Peran Inspektorat Kabupaten/Kota Sebagai Lembaga Pengawasan Internal Pemerintah Daerah Sebagai Lembaga Pengawasan Internal Pemerintah DaerahMenuju Tata Kepemerintahan Daerah Yang Baik. Hukum dan Dinamika Masyarakat, pp. 114-126.

Kahfi, A., 2014. Harun M. Husin, Pengelolaan dan Penegakan Hukumnya dalam Artikel Kejahatan Lingkungan Hidup. Al Daulah Jurnal Hukum Pidana \& Ketatanegaraan, pp. 206-216.

Nasional, D. P., 2012. Kamus Besar Bahasa Indonesia Pusat Bahasa. Jakarta: Gramedia Pustaka Utama.

Siahaan, N., 2017. Beberapa Masalah Tentang Tanggung Jawab Ganti Rugi Perdata Pencemaran Lingkungan Hidup. Jurnal Hukum \& Pembangunan, pp. 588-597

Akib, M., 2012. Politik Hukum Lingkungan. Jakarta: PT. Raja Grafindo Persada.

Berge, T. J., 1994. Recent Development in General Administrative Law in The Nederlands.. Belanda: Utrecht.

Akib, M., 2015. Intsrumen Penegakan Hukum Lingkungan dan Peermasalahannya. Yogyakarta: Graha Ilmu.

Akib, M., 2014. Hukum Lingkungan Perspektif Global dan Nasional. pertama penyunt. Jakarta: RajaGrafindo Perkasa.

Listiyani, N., 2018. Political Law on the Environment: The Authority of the Government and Local Government to File Litigation in Law Number 32 Year 2009 on Environmental Protection and Management. Resources, pp. 1-13. 